\title{
Study of Microbial Contamination in Broilers and Drug Sensitivity in Modern Abattoirs in Khartoum State, Sudan
}

\author{
M. E. Elshinnawi", M. I. M. Fangama, Y. A. Shuaib, E. S. M. Siham and M. A. Adalla \\ ${ }^{1}$ Department of Public Health, Ministry of Health, Qatar \\ ${ }^{2}$ College of Veterinary Medicine, Sudan University of Science and Technology, Sudan \\ *Corresponding author
}

\section{A B S T R A C T}

K e y w o r d s
Bacteria, Broilers,
$\begin{aligned} & \text { Drug, } \\ & \text { Contamination }\end{aligned}$
Article Info
$\begin{aligned} & \text { Accepted: } \\ & \text { 04 November } 2020 \\ & \text { Available Online: } \\ & 10 \text { December } 2020\end{aligned}$

\section{Introduction}

The consumption of poultry meat increased worldwide within the last decades (FAO, 1993; McNamara, 1997; Mead, 1997). Competition for an increased share of the poultry meat market centers on lowering the price, thus making poultry more attractive for the consumers. Therefore, modern poultry processing requires a high rate of throughput to meat consumers demand. With complete mechanization and automation, the number of slaughtered birds in many processing plants can reach 12000 birds per hour (Jame et al., 2000).During the slaughter process of poultry different microorganisms contaminate meat and most frequently Gram-positive rod and micrococci and also Gram-negative bacteria in final product, including enterobacteria (IMead, 1989; Zivkovic, 2001; Kozacinski et al., 2006). Foodborne pathogens can be introduced also to the food during processing, storage and preparation from infected humans who handle the food or by cross contamination from other raw agricultural products (Hodberg et al., 1994). Dirty worker hands, clothes, equipments of slaughterhouse acted as intermediate sources of contamination of meat (Gill, 1998; Gilmour $e t$ al., 2004; Abdelsadig, 2006; Abdalla et al., 
2009). After evisceration with poor hygienic management considered as sources of microbial contamination. Also bacterial contamination on processed broiler carcasses can be originated from farms (Plant, environment, equipments and employees). Therefore the hygienic measures must be from farm which considers impact on the health of both animals and humans working in the poultry meat industry (Ahmed et al., 2013). The contamination by bacteria can be caused on food in different parts of the carcass at any stage of operation (Kabour et al., 2012). Bacterial contamination by Salmonella spp. using viable counts (Omer et al., 2016) considered highest after washing and chilling than E. coli. Also bad drainage was identified to be most important rich factor associated with Salmonella spp. (Rammad et al., 2014). Bird feathers participated in bacteria and contamination with table for manual pluck finishing during processed meat poultry and this leading to increase the bacterial load (Morar et al., 2008). Hazard Analysis Critical Control Points (HACCP) is well- accepted systemic program for identification and control of microbiological hazards in all steps of poultry processing and industries and must be implemented this program to serve both external and internal market (Unnevehr and Jensen, 1996; McNamara,1997; Jimenez et al., 2002; Galhardo et al., 2006). The modern poultry industries can produce market ready broiler chickens in less than six weeks and this done through genetic selection, improved feeds and keen health management practices involving usage of antibiotic as therapeutic agents to treat bacterial diseases in intensive farming system (Apata, 2009). Resistant strains from the poultry gut readily soil poultry carcasses and when consume by human that alter his endogenous flora (Vander Bogaard and Stobberingh, 2001). Gene transferoccurs majorly in vivo between bacteria and gastrointestinal tract bacteria and pathogenic bacteria and identical resistant genes are present in diverse bacterial species from different hosts (Scott, 2002). The aim of the study to identify bacteria contaminated poultry carcasses and to determine the most effective antibiotic to isolated bacteria.

\section{Materials and Methods}

\section{Area of the study}

The swab samples were collected from broiler modern abattoir in Khartoum state- Sudan.

\section{Collection of samples}

A total of 154 swab samples were taken from the breast, back, leg and neck after hanging in the slaughter area, after bleeding, after scalding, after washing, after chilling, from slaughtering knives, scalding water, packing machine and hands of the workers (Bryan, 1980). The organism was removed from each swab by shaking for a few minutes in $10 \mathrm{ml}$ sterile $0.5 \%$ peptone water.

\section{Bacteriology}

The isolation and identification of bacteria were carried out according to the methods of Barroow and Feltham (2003). The viable count (TVCs) of the isolated microorganism was also used (Harrigan and MacCance, 1976).

\section{Antibiotic sensitivity test}

All bacteria isolated were tested for resistance to some antibiotic and these were gentamyin (Gen), amoxicillin (Amc), ciprofloxacin(Cip), vancomycin (Van), erythromycin(Ery), penicillin(P), chloronphenicol (C), (Maxxi care medical laboratories Ltd, Nigeria). The sensitivity test was used as described by Prescett et al., (2005). 


\section{Statistical analysis}

The collected data were analyzed with SPSS software (Statistical Package for the Social Science, version Il.5SSPS Inc and Chicago, IL, USA). All bacterial counts were converted to $\log _{10} \mathrm{CFU} / \mathrm{Cm}^{-2}$ for analysis and ANOVA were performed. Statistical significance was set at $\mathrm{P}$ value of $<0.05$.

\section{Results and Discussion}

As shown in Table 1 the highest level of TVCs in the breast $8.15 \pm 0.10$, the back $5.5 \pm$
0.10 and the neck $9.50 \pm 0.10$ after evisceration. But the level increased in the leg (6.6 \pm 0.10$)$ after bleeding. Statistically, there was no significant difference $(\mathrm{P}>0.05)$. The high level of contamination by E. coli was $62.5 \%$ after defeathering and Salmonella spp. was $50.0 \%$ after chilling, while Proteus spp. the contamination was $(12.5 \%)$ at hanging, after scalding and after washing. But the bacterial level increased due to Pseudomonas spp. at washing only. The contamination of Staphylococcus spp. was $62.5 \%$ after scalding (Table 2).

Table.1 Comparison of Total viable count of bacteria $\left(\log _{10} \mathrm{CFU} / \mathrm{Cm}^{2}\right)$ at different sites and operational points (No. 154) in broiler abattoir Khartoum state

\begin{tabular}{|l|l|l|l|l|l|l|l|l|}
\hline Sites & \multicolumn{7}{|c|}{ Critical Control Points } & \multicolumn{1}{|c|}{ p- } \\
& A & B & C & D & E & F & G \\
\hline Breast & $5.35 \pm 0.04$ & $5.56 \pm 0.10$ & $3.62 \pm 0.50$ & $6.48 \pm 0.10$ & $8.15 \pm 0.10$ & $5.54 \pm 0.10$ & $3.45 \pm 0.04$ & NS \\
\hline Back & $3.34 \pm 0.04$ & $4.60 \pm 0.01$ & $5.38 \pm 0.10$ & $5.29 \pm 0.10$ & $5.56 \pm 0.10$ & $2.13 \pm 0.03$ & $5.46 \pm 0.10$ & NS \\
\hline Leg & $5.50 \pm 0.04$ & $6.60 \pm 0.10$ & $4.27 \pm 0.10$ & $4.33 \pm 0.01$ & $4.56 \pm 0.10$ & $4.66 \pm 0.10$ & $3.62 \pm 0.05$ & NS \\
\hline Neck & $6.38 \pm 0.04$ & $5.65 \pm 0.10$ & $4.61 \pm 0.10$ & $5.57 \pm 0.10$ & $9.50 \pm 0.10$ & $6.54 \pm 0.10$ & $5.54 \pm 0.10$ & NS \\
\hline
\end{tabular}

A: Hang slaughtering, B: After bleeding, C: After scalding, D: After defeathering, E: After evisceration, F: After washing, G: After chilling and NS: Not significant at P-value 0.05

Table.2 The number of bacteria isolated from operational points of the carcasses in broiler carcasses in abattoir, Khartoum state

\begin{tabular}{|c|c|c|c|c|c|}
\hline \multirow[t]{2}{*}{ CCPs } & \multicolumn{5}{|c|}{ Isolated bacteria } \\
\hline & E. coli & Salmonella & Proteus & Pseudomonas & Staphylococcus \\
\hline At hanging $(n=16)$ & $\begin{array}{c}0 \\
(0.0 \%)\end{array}$ & $\begin{array}{c}6 \\
(37.5 \%)\end{array}$ & $\begin{array}{c}2 \\
(12.5 \%)\end{array}$ & $\begin{array}{c}0 \\
(0.0 \%)\end{array}$ & $\begin{array}{c}8 \\
(50 \%)\end{array}$ \\
\hline After bleeding $(n=16)$ & $\begin{array}{c}4 \\
(25 \%)\end{array}$ & $\begin{array}{c}4 \\
(25 \%)\end{array}$ & $\begin{array}{c}0 \\
(0.0 \%)\end{array}$ & $\begin{array}{c}0 \\
(0.0 \%)\end{array}$ & $\begin{array}{c}8 \\
(50 \%)\end{array}$ \\
\hline After scalding $(n=16)$ & $\begin{array}{c}2 \\
(12.5 \%)\end{array}$ & $\begin{array}{c}2 \\
(12.5 \%)\end{array}$ & $\begin{array}{c}2 \\
(12.5 \%)\end{array}$ & $\begin{array}{c}0 \\
(0.0 \%)\end{array}$ & $\begin{array}{c}10 \\
(62.5 \%)\end{array}$ \\
\hline $\begin{array}{l}\text { After defeathering } \\
(n=16)\end{array}$ & $\begin{array}{c}10 \\
(62.5 \%)\end{array}$ & $\begin{array}{c}2 \\
(12.5 \%)\end{array}$ & $\begin{array}{c}0 \\
(0.0 \%)\end{array}$ & $\begin{array}{c}0 \\
(0.0 \%)\end{array}$ & $\begin{array}{c}4 \\
(25 \%)\end{array}$ \\
\hline $\begin{array}{l}\text { After evisceration } \\
(n=16)\end{array}$ & $\begin{array}{c}8 \\
(50 \%)\end{array}$ & $\begin{array}{c}4 \\
(25 \%)\end{array}$ & $\begin{array}{c}0 \\
(0.0 \%)\end{array}$ & $\begin{array}{c}0 \\
(0.0 \%)\end{array}$ & $\begin{array}{c}4 \\
(25 \%)\end{array}$ \\
\hline After washing $(n=16)$ & $\begin{array}{c}8 \\
(50 \%)\end{array}$ & $\begin{array}{c}2 \\
(12.5 \%)\end{array}$ & $\begin{array}{c}2 \\
(12.5 \%)\end{array}$ & $\begin{array}{c}2 \\
(12.5 \%)\end{array}$ & $\begin{array}{c}2 \\
(12.5 \%)\end{array}$ \\
\hline After chilling $(n=16)$ & $\begin{array}{c}6 \\
(37.5 \%)\end{array}$ & $\begin{array}{c}8 \\
(50 \%)\end{array}$ & $\begin{array}{c}0 \\
(0.0 \%)\end{array}$ & $\begin{array}{c}0 \\
(0.0 \%)\end{array}$ & $\begin{array}{c}2 \\
(12.5 \%)\end{array}$ \\
\hline Total $(n=112)$ & 38 & 28 & 6 & 2 & 38 \\
\hline
\end{tabular}


Table.3 Bacterial contamination in control points in broilers - Khartoum state

\begin{tabular}{|c|c|c|c|c|c|c|}
\hline \multirow[t]{2}{*}{ CCPs } & \multirow{2}{*}{$\begin{array}{l}\text { Count } \\
\log _{10} \mathrm{CFU} / \mathrm{cm}^{2}\end{array}$} & \multicolumn{5}{|c|}{ Isolated bacteria } \\
\hline & & E. coli & Salmonella & Proteus & Pseudomonas & Staphylococcus \\
\hline Slaughter Knife $(n=6)$ & 4.43 & $3(50 \%)$ & $2(33.30 \%)$ & $0(0.00 \%)$ & $0(0.0 \% 0)$ & $2(33.30 \%)$ \\
\hline Scalding water $(n=6)$ & 2.54 & $0(0.00 \%)$ & $0(0.00 \%)$ & $2(33.30 \%)$ & $4(66.70 \%)$ & $0(0.00 \%)$ \\
\hline $\begin{array}{l}\text { Packing machine } \\
(n=6)\end{array}$ & 2.59 & $1(16.70 \%)$ & $0(0.00 \%)$ & $0(0.00 \%)$ & $0(0.00 \%)$ & $4(66.70 \%)$ \\
\hline $\operatorname{Total}(n=18)$ & - & 4 & 2 & 2 & 4 & 6 \\
\hline
\end{tabular}

Table.4 Isolated bacteria from the hands of the workers (n-24) at some control points in broiler abattoir -Khartoum state

\begin{tabular}{|c|c|c|c|c|c|c|}
\hline \multirow[t]{2}{*}{ Point } & \multicolumn{6}{|c|}{ Hands of workers } \\
\hline & $\begin{array}{l}\text { Count } \\
\log _{10} \text { CFU/cm } \\
2\end{array}$ & E. coli & Salmonella & Proteus & Pseudomonas & Staphylococcus \\
\hline At hanging $(n=6)$ & 5.54 & $0(0.0 \%)$ & $1(16.7 \%)$ & $0(0.0 \%)$ & $0(0.0 \%)$ & $2(33.3 \%)$ \\
\hline $\begin{array}{l}\text { During evisceration } \\
(n=6)\end{array}$ & 9.49 & $0(0.0 \%)$ & $1(16.7 \%)$ & $1(16.7 \%)$ & $2(33.3 \%)$ & $2(33.3 \%)$ \\
\hline Cutting (n=6) & 5.48 & $4(66.7 \%)$ & $0(0.0 \%)$ & $0(0.0 \%)$ & $0(0.0 \%)$ & $1(16.7 \%)$ \\
\hline Packing $(n=6)$ & 3.58 & $1(16.7 \%)$ & $1(16.7 \%)$ & $0(0.0 \%)$ & $0(0.0 \%)$ & $4(66.7 \%)$ \\
\hline Total $(n=24)$ & - & 5 & 3 & 2 & 2 & 9 \\
\hline
\end{tabular}

Table.5 Susceptibility of contaminated bacteria at control points in abattoir, Khartoum state

\begin{tabular}{|l|c|c|c|c|c|}
\hline Antibiotic & Staphylococcus & $\boldsymbol{E}$. coli & Proteus & Salmonella & Pseudomonas \\
\hline Gem /10 & 3.0 & 2.5 & 2.4 & 2.4 & 2.3 \\
\hline Ame/ 10 & 2.8 & 2.4 & 2.4 & 2.2 & 2.0 \\
\hline Cip/5 & 2.5 & 2.5 & 2.2 & 2.3 & 2.1 \\
\hline Van/ 30 & 2.3 & 2.4 & 2.3 & 2.2 & 2.1 \\
\hline E/10 & 1.5 & 1.6 & 1.5 & 1.4 & 1.2 \\
\hline P/10 & 0.9 & 0.8 & 0.8 & 0.7 & 0.8 \\
\hline C/30 & 0.9 & 0.9 & 0.7 & 0.5 & 0.5 \\
\hline
\end{tabular}

Gem: Gentamycin, Amc: Amoxicillin, Cip: Ciprofloxacin, Van; Vancomycin, E: Erythromycin; P: Penicillin and C: Chloranphenicol

The total viable count and contaminated bacteria of slaughter knives, scalding water and packing machine were shown in table 3. The organism E. coli was high in knives, but Pseudomonas spp. in scalding water and Staphylococcus spp. in packing machine. In table 4, the TVCs was high during evisceration (9.49 $\log _{10} \mathrm{CFU} / \mathrm{cm}^{-2}$ ), but low in packing machine $\left(3.58 \log _{10} \mathrm{CFU} / \mathrm{cm}^{-2}\right)$. While high level of contamination of E. coli $(66.7 \%)$ at cutting, whereas Staphylococcus $(66.7 \%)$ at packing. Table 5 summarized the sensitivity of bacteria isolated and all isolates were sensitive to gentamycin.

In the present study, there is no significant difference between the sites of the carcasses and critical operational points $(\mathrm{P}>0.05)$ in (Table 1). This indicated that broilers can be contaminated by bacteria specially human 
pathogenic bacteria (Goksoy et al., 2004). The presence of E. coli and Salmonella spp, in all critical points (Table 2, 3 and 4) showed that these bacteria contaminated birds from farms and transportation (Kabour et al., 2012; Ahmed et al., 2013). The feathers and evisceration were considered the source of contamination of these gram negative bacteria (Morar et al., 2008; Mohamed -Noor et al., 2012). The species Salmonella in this study (Table 1) increases after chilling and this result in accordance with result of Afshin et al., (2013) who reported that food borne disease caused by microorganism contaminated poultry meat. Also the presence of this organism after chilling in agreement with Thomas and McKeckin (1980); Rammad et al., (2014). But this result in contrast with Yang et al., (2002) who said that this species do not grow after chilling. The study showed that E. coli, Pseudomonas spp. and Salmonella spp. are bacteria contaminated broilers meat, this is in agreement with study of Jeffery et al., (2003), Mead (2004) and Kabour et al., (2012) who reported that the hands of the workers are the source of contamination. In these results Proteus spp. and Staphylococcus spp. were found in control points. The contamination by these organisms may be due to farm litter or improper slaughtering process Mohamed Noor et al., 2012; Ahmed et al., 2014, in this study all isolated bacteria were sensitive to gentamycin (Table 5). This amino glycoside is considered to be the drug of choice for treatment of bacterial infections, because of broad spectrum mechanism action in cell bacteria (Adams, 2001). In conclusion poultry carcasses can be contaminated at any critical control points, but applying of slandered methods of hygiene leading to safe broiler meat for consumption.

\section{References}

Abdalla, M.A., Siham, E. Suliman and Y.Y.H.A. Alian. (2009). Microbial contamination of sheep carcasses at modern slaughterhouse in Khartoum state. Sud. J. Sci. Anim. Hsub. 48 (1\&2) pp. 51-56.

Abdalla, A.A., Siham, E. Suliman; Yassir, A. Shuaib; Mohamed, M.A. Bdalla (2013). Bacteriological study of poultry meat in semi-automatic abattoir in Khartoum state-Sudan. Journal of Agricultural and Veterinary Science, Vol. 4 (2), 8287.

Adams, R.H. (2001). Veterinary Pharmacology and Therapeutics. Eighth edition. A Blackwell Publishing Company, Iowa State Press, 2121 State Avenue, Ames, Iowa.

Abdelsadig MB. (2006). Study of some critical control points in Elkadaro slaughterhouse. MSc in public health. University of the Academy of Medical Science and Technology. 48: 1-2.

Ahmed A. Abdalla., S.E. Suliman., Yassir Adam Shuaib., and M.A. Abdalla. (2013). Bacteriological Study of Poultry Meat in Semi-Automatic Abattoir in Khartoum State, Sudan. Journal of Agricultural and Veterinary Science (SUST), Vol 14(2) PP.82-87

Afshin, J; Saeid, S. and Resa, G.(2013). Study on Salmonella contamination in poultry lean meat and meat with skin in Tabriz slaughterhouse, African Journal of Biotechnology, 13(1): 131184.

Apata, D.F. (2009). Antibiotic resistance in poultry. Int. J. Poult. SCi., 8: 404=408

Barrow, G. I. and Feltham, R.K.A. (1993). Manual for the Identification of Medical Bacteria (3rd ed.), Cambridge University Press, Cambridge

Bell, R.G., Hathaway, S.C. (1996). The hygienic efficiency of conventional and inverted lamb dressing systems. Journal of Applied Microbiology. 81, 
pp. 225- 234.

Bryan, F.L. (1980). Poultry and meat products (Edited by Sillcker, J.H; Elliot, R.P., Baird- Parker, A.C., Bryan, F.L., Christain, J.H.B., Clark, D.S., Olson, J.C. and T.A. Roberts): In Microbial Ecology of Foods, Vol.2:Food Commodities. Pp. 410-458.

Food and Agriculture Organization (FAO) (1993). Record poultry meat consumption. Poult. Int. 32: 70-72.

Galhardo, J.A., Lopes, M., Dliveira, J.T. (2006). Eficacia dos Tanques de preresfriament onareducao de contaminaco bactrianaemcarcacas de frago. Cicencias Agrarias

Gill, CO (1998). Microbiological contamination of meat during slaughter and butchering of cattle, sheep and pigs. In: DAVIES, A., BOARD, R (EdS.). The Microbiology of Meat and Poultry. 'London: Blackie

Glimour, A; K.A. Murry and R.H. Madden, (2004). Determination of the principal points of products contamination during beef carcass dressing process in Northern Ireland. J Food Prot, 67: 1494-1496.

G ö ksoy, E.Ö., Kirkan, S. and K ölc, F. (2004). Microbiological quality of broiler carcasses during processing in two slaughter houses in Turkey. Poultry Science, 83 (8), 1427-1432.

Harrigan, W.F. and McCance, M.E. (1976). Laboratory methods. In Food and Dairy microbiology. Academic Press New York.

Hedberg, C.W. MacDonald, K.L., Osterholm, M.T. (1994). Changing epidemiology of food- borne disease: a Minnesota perspective. Clin. Infect. Dis., 18: 671-682.

James, C., E.O. Gokso; E.L. Corry and S.J. James (2000). Surface pasteurization of poultry meat using steam at atmospheric pressure. J. Food Eng.,
45: 111-117.

Jeffery, B; Donald, AB; Gill, CO. (2003). Implementation of validated HACCP system for the control of microbiological contamination of pig carcass at a small abattoir. Can. Vet. J. 44: 1 .

Jimenez, S.M., Salsi, M.S. and Tiburzi, M.C.(2002). A comparison between broiler chicken carcasses with and without visible fecal contamination during the slaughtering process on hazard identification of Salmonella spp. Journal of Applied Bacteriology, 93(4), 593-108.

Kabour, A.K.G., S.E. Suliman; A. Ghali and M.A. Abdalla (2012). Microbial Contamination of Chicken Carcasses during Processing in Khartoum State. Assiut Vet. Med. J., Vol. 58No 134,279282.

Kozacinski, L., M. Hadziosmanovic; N. Zdolec (2006). Microbiological quality of poultry meat on the Croation market. Vet. Arhiv, 76, 305313.

McNamara, A.M. (1997). Generic HACCP application in broiler slaughter and processing. National Advisory Committee on Microbiological Criteria for Foods. Food Prot., 26 (5): 462- 604, pp 579-604.

Mead G.C. (1989). Hygiene problems and control of process contamination. [Edited by Mead G.C.] In Processing of Poultry. Elsevier Science Publishers Ltd. 183-220.

Mead, G. C. (1997). Safety of Poultry Products Past, Present and Future. Meat and Poultry. News8, 26-27.

Mead, G.C. (2004). Microbiological quality of poultry meat: Review. Brazilian Journal of Poultry Science 6(3), 135 142.

Mohamed-Noor, S.E. YA Shuaib, S.E. Suliman; M.A. Abdalla (2012). Study 
of microbial contamination of broilers in modern abattoirs in Khartoum state. AUDJG-Food Technology, 6(1), 7480.

Morar, A., Milovan, G.H., Sala, C. and Stanchescu, I. (2008). Establishing the bacterial control points in poultry slaughterhouse. Lucrari Stuntsfice Medicina Veterinara, Vool.16: 704708.

Omer, A.K., Mohamed, M.M., AwadAlkarim, A.A., Sluman, S.E., Abdalla, M.A. (2016). Detection of Salmonella spp. and Escherichia coli in poultry carcasses at abattoir in Khartoum state, Sudan. Sudan Journal of Science and technology, Vol. 17 (1): 66-72.

Prescott, L.M., J.P. Hearly, D.A. Klein (2005). Microbiology, $6^{\text {th }}$ Edn. McGraw Hill Co., New York, London.

Rammad, S.Y., Suliman, S.E., Shuaib, Y.A., Abdalla, M.S. (2014). Prevalence and risk factors of Salmonella species in poultry at abattoir in Khartoum state. DOI: $10,13140 / R G 2.1 .313763$.

Scott, K.P. (2002). The role of conjugative transportation in spreading antibiotic resistance between bacteria that inhabit the gastrointestinal tract. Cell. Mool. Life Sci., 59: 20712082.

Thamas, C.J. and McMeeken, T.A. (1980).
Contamination of broiler carcass s, skin during commercial processing procedure: an electron microscopic study. Applied and Environmental Microbiology, 4 (1): 133-144.

Unnevehr, L.J, and H. H. Jensen (1996). HACCP as regulatory innovation to improve food safety in meat industry. Am. J. Agric. Econ., 20: 186-201.

Vander Bogaard, A.E. and E.E. Stobbrringh. (2001). Recent trend in antibiotic usage and bacterial resistance. Drugs, 65: 102110.

VizzierThaxton, Y., Cason, N.A., Cox, S.E. Morris and J.P. Thaxton (2003).The decline of academic poultry Science in the United States of America. World Poultry Sci. J., 59:303313.

Yang, H.S., Wang, Y. Li and M.G.Johnson (2002). Predictive models for the survival / death of Campylobacter jejune and Salmonella typhimurium in poultry scalding and chilling. Journal of Food Science, 67: 1836-1842.

Zikovic, J. (2001). Higijena I technologij a mesa. Veterinarskosanitrntnadzorzivatin jazaklanje I mesa. 1. Dio.11 dopunjenoizdanje. Uredioidopunio M. Hadziosmanovi. Veterinaskifakiltets veucilista u zaprebu.

\section{How to cite this article:}

Elshinnawi, M. E., M. I. M. Fangama, Y. A. Shuaib, E. S. M. Siham and Adalla, M. A. 2020. Study of Microbial Contamination in Broilers and Drug Sensitivity in Modern Abattoirs in Khartoum State- Sudan. Int.J.Curr.Microbiol.App.Sci. 9(12): 155-161. doi: https://doi.org/10.20546/ijcmas.2020.912.021 